\title{
Electrolyte balance and voice in hemodialysis patients
}

\author{
Beuy Joob ${ }^{1}$ (D) Viroj Wiwanitkit ${ }^{2}$
}

Received: 10 September 2018 / Accepted: 15 September 2018 / Published online: 18 September 2018

c) Springer-Verlag GmbH Germany, part of Springer Nature 2018

\section{Dear Editor,}

We read the publication on "The effect of electrolyte balance on the voice in hemodialysis patients" with a great interest [1]. Sagiroglu and Doganer noted that "uric acid was the agent creating a reduction in vocal cord vibration, the agent increasing the difference between vibration waves was $\mathrm{Na}+$, and creatinine increased the NHR rate [1]." Indeed, there are other possible factors that might affect the voice in hemodialysis. As a stressful event, the inflammation might occur according to the dialysis [2]. To rule out the concurrent effect of possible hidden inflammation, the erythrocyte sedimentation rate (ESR) might be additional used as a control parameter in the present study. Finally, the problem of laboratory interference on measurement of uric acid in the patients with dialysis should be mentioned [3]. If the colorimetric test is used for measurement of uric acid, the error can be expected in cases undergoing dialysis [3]. In addition, the concurrent use of some common drugs such as acetaminophen also result in aberrant serum uric acid result in hemodialysis patient [4].

\section{Compliance with ethical standards}

Conflict of interest The authors declare that they have no conflict of interest.

\section{References}

1. Sagiroglu S, Doganer A (2018) The effect of electrolyte balance on the voice in hemodialysis patients. Eur Arch Otorhinolaryngol. https://doi.org/10.1007/s00405-018-5098-x (epub ahead of print)

2. Borawski J, Myśliwiec M (2001) The hematocrit-corrected erythrocyte sedimentation rate can be useful in diagnosing inflammation in hemodialysis patients. Nephron 89(4):381-383

3. James DR, Price CP (1984) Interference in colorimetric reactions for measuring hydrogen peroxide. Ann Clin Biochem 21(Pt 5):398-404

4. Tanner R, Arund J, Fridolin I, Luman M (2013) Paracetamol interference in uric acid levels in uremic patients revealed by monitoring spent dialysate. ISRN Nephrol 1:515292

This comment refers to the article available online at https://doi. org/10.1007/s00405-018-5098-x.

Beuy Joob

beuyjoob@hotmail.com

1 Sanitation 1 Medical Academic Center, Bangkok, Thailand

2 Dr. D. Y. Patil University, Pune, India 